\title{
Cryogenic cave carbonates from the Cold Wind Cave, Nízke Tatry Mountains, Slovakia: Extending the age range of cryogenic cave carbonate formation to the Saalian
}

\author{
Karel Žák ${ }^{1}$, Helena Hercman ${ }^{2}$, Monika Orvošová ${ }^{3}$, Ivana Jačková ${ }^{4}$
}

\begin{abstract}
:
Žák K., Hercman H., Orvošová M. and Jačková I. 2009. Cryogenic cave carbonates from the Cold Wind Cave, Nízke Tatry Mountains, Slovakia: Extending the age range of cryogenic cave carbonate formation to the Saalian. International Journal of Speleology, 38(2), 139-152. Bologna (Italy). ISSN 0392-6672.

Cold Wind Cave, located at elevations ranging between 1,600 and 1,700 m a. s. I. in the main range of the Nízke Tatry Mountains (Slovakia), is linked in origin with the adjacent Dead Bats Cave. Together, these caves form a major cave system located within a narrow tectonic slice of Triassic sediments. Both caves have undergone complex multiphase development. A system of sub-horizontal cave levels characterized by large, tunnel-like corridors was formed during the Tertiary, when elevation differences surrounding the cave were less pronounced than today. The central part of the Nízke Tatry Mountains, together with the cave systems, was uplifted during the Neogene and Lower Pleistocene, which changed the drainage pattern of the area completely. The formation of numerous steep-sloped vadose channels and widespread cave roof frost shattering characterized cave development throughout the Quaternary.

In the Cold Wind Cave, extensive accumulations of loose, morphologically variable crystal aggregates of secondary cave carbonate ranging in size between less than $1 \mathrm{~mm}$ to about $35 \mathrm{~mm}$ was found on the surface of fallen limestone blocks. Based on the $C$ and $\mathrm{O}$ stable isotope compositions of the carbonate $\left(\delta^{13} \mathrm{C}: 0.72\right.$ to $6.34 \%, \delta^{18} \mathrm{O}:-22.61$ to $-13.68 \%$ V-PDB) and the negative relation between $\delta^{13} \mathrm{C}$ and $\delta^{18} \mathrm{O}$, the carbonate crystal aggregates are interpreted as being cryogenic cave carbonate (CCC). Published models suggest the formation of CCC in slowly freezing water pools, probably on the surface of cave ice, most probably during transitions from stadials to interstadials. Though the formation of these carbonates is likely one of the youngest events in the sequence of formation of cave sediments of the studied caves, the ${ }^{230} \mathrm{Th} /{ }^{234} \mathrm{U}$ ages of three samples $(79.7 \pm 2.3,104.0 \pm 2.9$, and $180.0 \pm 6.3 \mathrm{ka}$ ) are the oldest so far obtained for CCC in Central Europe. This is the first description of CCC formation in one cave during two glacial periods (Saalian and Weichselian).
\end{abstract}

Keywords: cryogenic cave carbonate, U-series dating, carbon and oxygen stable isotopes, Western Carpathians, Nízke Tatry Mountains.

Received 17 March 2009; Revised 24 April 2009; Accepted 20 May 2009

\section{INTRODUCTION}

The freezing of karst waters in caves frequently results in the precipitation of a specific type of secondary cave carbonate, here referred to as cryogenic cave carbonate $(\mathrm{CCC})$. This type of cave carbonate is formed by the expulsion of dissolved $\mathrm{Ca}-\mathrm{HCO}_{3}$ solutes from freezing solutions. Depending

1. Institute of Geology AS CR, v. v. i., Rozvojová 269, 16500

Praha 6 - Lysolaje, Czech Republic; zak@gli.cas.cz

2. Institute of Geological Sciences, Polish Academy of Sciences, Twarda 51/55, 00-818 Warszawa, Poland; hhercman@twarda. pan.pl

3. The Slovak Museum of Nature Protection and Speleology,

Školská 4, 03101 Liptovský Mikuláš, Slovakia; orvosova@ smopaj.sk

4. Czech Geological Survey, Klárov 3, 11821 Praha 1, Czech

Republic; ivana.jackova@geology.cz on the initial dissolved mineral load of the solution, freezing rate, presence or absence of accompanying evaporation/sublimation, and open/closed character of the cave environment with respect to $\mathrm{CO}_{2}$ escape, a wide range of $\mathrm{CCC}$ shapes and sizes, with varied $\mathrm{C}$ and $\mathrm{O}$ stable isotope compositions can be precipitated. Typically, the rapid freezing of water results in finegrained precipitates (i.e., powders), whereas the slow freezing of water tends to form coarse-grained CCC (e.g., Žák et al., 2004; Lacelle, 2007; Žák et al., 2008; Spötl, 2008). The formation of coarse-grained CCC precipitates seems to be restricted to Central European caves that were located beyond the glacial limits of Pleistocene glaciations (Žák et al., 2004; Richter \& Riechelmann, 2008; Richter et al., 2008). Exact nature of the environment in which the coarsegrained CCC precipitated is unknown. Published model suppose its formation in cave voids located within the permafrost zone, into which penetrated 
water during melting of surface permafrost zone during interstadials, or through larger karst conduits not completely blocked by ice (Žák et al., 2004; Richter \& Riechelmann, 2008). An existence of intrapermafrost liquid water and of water flow in karst conduits within the permafrost zone below the thermoactive layer is documented in Ford \& Williams (2007, p. 421-427). As of yet, there have been no documentations of the presence of coarse-grained CCC from caves located within the present-day permafrost zone.

Coarse-grained CCC occurs as accumulations of loose (i.e., not cemented together) carbonate crystals and crystal aggregates, deposited on the bottom of larger cave spaces. Coarse-grained CCCs have grain size ranging from less than $1 \mathrm{~mm}$ to about $30 \mathrm{~mm}$, and are morphologically quite complex, frequently presenting many crystal intergrowths and skeletal crystals. X-ray diffraction data identified calcite as the only mineral present in CCC; nevertheless, the initial presence of some metastable carbonate phases, with later transition to calcite, is possible (e.g., Lacelle et al., 2009; this study has shown through SEM analysis that fine-grained CCC probably initially consists of vaterite, later transformed to calcite upon exposure to warmer temperature or water).

CCC precipitates differ from the common Quaternary speleothems of the studied area (i.e., stalagmites, stalactites, flowstones) as the CCC has a wider carbonate $\mathrm{C}$ and $\mathrm{O}$ stable isotope composition, usually with very low $\delta^{18} \mathrm{O}$ values down to $-25 \%$ o (V-PDB; for stable isotope data on CCC see Durakiewicz et al., 1995; Clark \& Lauriol, 1992; Žák et al., 2004; Lacelle, 2007; Žák et al., 2008; Richter \& Riechelmann, 2008; Richter et al., 2008).

At present, coarse-grained CCCs were discovered from several caves of the Czech Republic, Germany, Poland, and Slovakia (general information on Central European karst areas of the Czech Republic, Poland and Slovakia can be found in Tyc, 2004). All of the CCC precipitates yielded U-series dating of Weichselian ages (14.5 to $61.0 \mathrm{ka}$ ). Geographically, all of these caves containing coarse-grained $\mathrm{CCC}$ were located at the time of $\mathrm{CCC}$ formation within the unglaciated zone between the southern limit of the European continental glaciation to the north, and that of the Alpine glaciation to the south. The sites therefore occur in a belt, which parallels the southern rim of Pleistocene continental glaciation (see Fig. 1 in Žák et al. 2008).

The oldest CCC (U-series dating: $\mathbf{3 6 . 0} \pm 1.2$ to $\mathbf{6 1 . 0} \pm 1.8 \mathrm{ka})$ known so far is from the Chelosiova Jama - Jaskinia Jaworznicka Cave System (Holy Cross Mountains), located close to the town of Kielce, Poland (Žák et al., 2004). The youngest coarse-grained CCCs discovered in Europe so far are from the Malachitdom Cave (Rheinish Slate Mountains, Germany; Richter \& Niggemann 2005). Richter \& Riechelmann (2008) provided U-series ages in the range from 15.61 \pm 0.20 to $\mathbf{1 4 . 4 8} \pm 0.12 \mathrm{ka}$ for the $\mathrm{CCC}$, which corresponds to the Pre-Bölling warming.

In this paper, chronologic and isotope geochemistry data are given for CCC from a site, recently discovered in a cave located close to the highest peak of the Nizke Tatry Mountains, Slovakia - Dumbier Mt. This site differs from the other known sites by its location at a relatively higher altitude, in an area, which contained valley glaciers during the glacial periods, especially on the northern side of the main range (Louček et al., 1960). Since the karst of the Dumbier area represents one of the most interesting karst areas of Slovakia and the whole Western Carpathians, and is practically unknown in the international literature, the geographic, geologic and speleological setting of the study area is given here in more detail.

\section{DESCRIPTION OF THE STUDY AREA}

The Nizke Tatry Mountains are one of the core mountain units of the Western Carpathians in Slovakia. The main East-West range is composed predominantly of pre-Alpine crystalline schists and granitic rocks, which were incorporated into the nappe structure of the Carpathian Orogen. The principal nappe structure resulted from compressional tectonogeny before the end of the Turonian. The present-day arc-horst structure of the Nizke Tatry Mountains was formed by differential uplift during the Tertiary. The Late Tertiary and Pleistocene uplift was important in determining the recent morphology of the area (Biely et al., 1992). The history of the rock cooling and uplift was further studied by Danišik et al. (2005), using the apatite fission track and (U-Th)/He methods. These authors concluded that cooling at the Oligocene/Miocene boundary (reflecting disintegration of the Paleogene sedimentary basin) was followed by reheating at $\sim 17$ $\mathrm{Ma}$, interpreted as the result of an increased thermal gradient during Miocene volcanism, occurring mostly in the internal part of the Carpathian Orogen. Subsequent cooling to present-day conditions related to the uplift followed after $\sim 17 \mathrm{Ma}$.

The uplift of the central part of the mountains was accompanied by widespread erosion of the Mesozoic sedimentary cover. Relics of this sedimentary cover and nappe units consisting of sedimentary rocks (including thick sequences of Mesozoic carbonate sediments with well developed karst) parallel the crystalline and granitic core unit, both from the south and the north. The karst of Horehronske Podolie developed on the south side of the crystalline core unit and karst of monoclinally-dipping limestone strata, with the famous caves of Demänovská and Jánska Valley, and the adjacent high elevations of Siná, Krakova Hola, and Ohnište was formed on the north side (Droppa, 1957; 1966).

In a tectonic position within granitic and metamorphosed rocks, in an area close to the highest peak of the Nizke Tatry Mountains, several narrow, steeply-dipping relics of Mesozoic sediments are preserved in a stripe about $14 \mathrm{~km}$ long, which together have an outcrop area of only several square km (Kubíny, 1961; Droppa, 1973; Bella, 2004). The significant vertical extent of these tectonic slices of sedimentary rocks (locally down to $1 \mathrm{~km}$ below the surface) is usually deeper than the width of their outcrop. Known caves here are most widespread in 


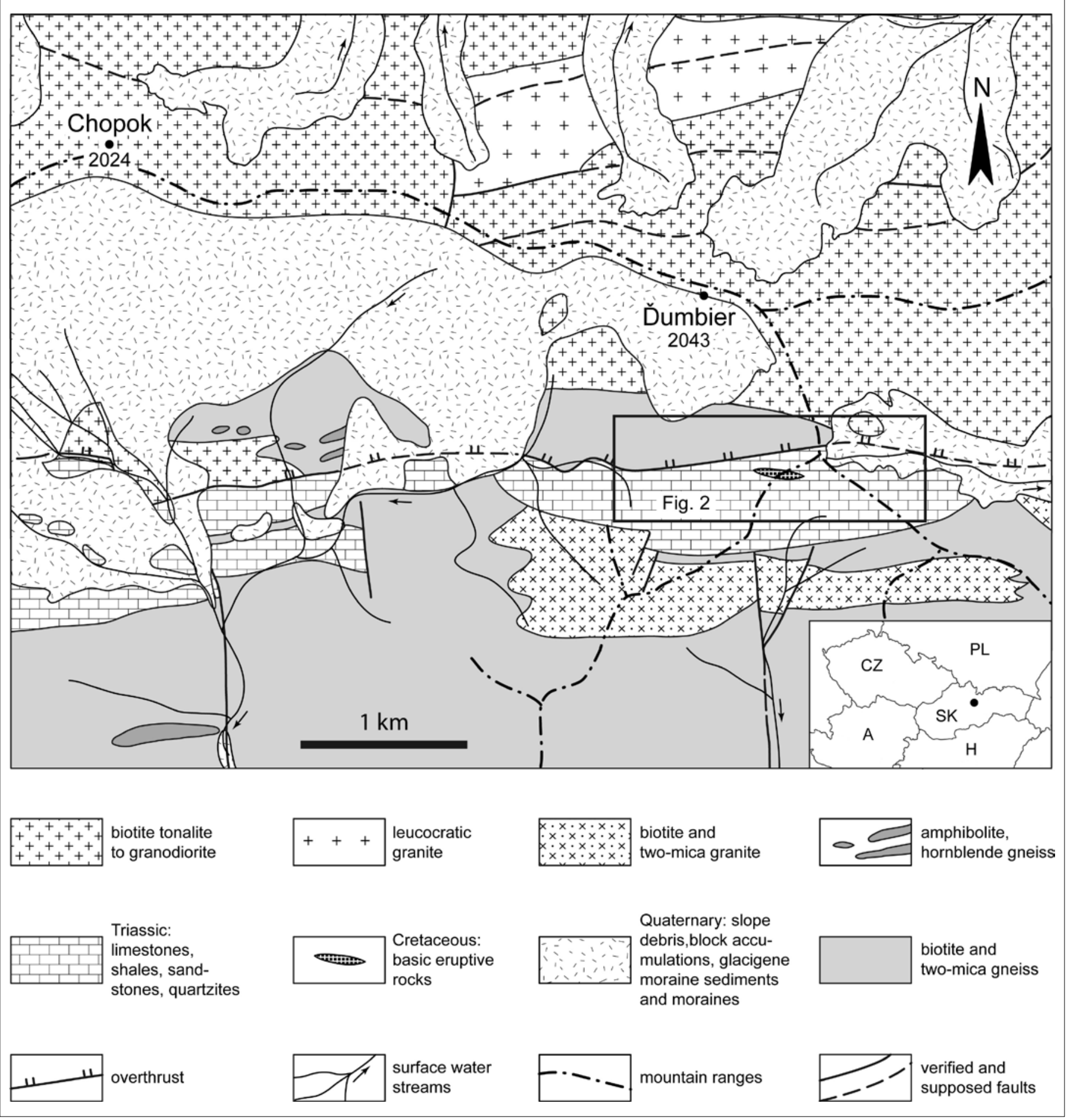

Fig. 1. Schematic map of the study area. Geology is after Biely et al. (1992)

a tectonic slice of Triassic sediments about $4.5 \mathrm{~km}$ long and only $350 \mathrm{~m}$ wide, located South East of Dumbier Mt. (2043 m a. s. 1., Fig. 1). The eastern part of this slice runs through southern slopes of the main mountain range and passes through a wide gap (1740 $\mathrm{m}$ a. s. 1.) into the northern slopes of the main range. Close to this gap, a south-forking branch of the main range called Kozie Chrbty ("Goat Ridges", a hogback) significantly exposes the limestone strata, and contains the most important caves (Figs. 1,2). Because the conditions were highly suitable for karstification (strongly tectonized, steeply dipping limestone strata with variable solubility, adjacent to a large region of silicate rocks), karst features already started to develop here in the Neogene (and possibly earlier), with continuing karst evolution (and destruction of old caves) up to the present-day.

During the Middle and Upper Pleistocene glacials, the Nizke Tatry Mountains contained several valley glaciers, especially in the valleys directed to the north from the main mountain range. Their extent is evidenced by lateral and terminal moraines (Louček et al., 1960). The studied caves are located above these valleys in an area which contains abundant surface periglacial features but was probably never continuously glaciated. No data have been published about the Pleistocene permafrost depth in the Nizke Tatry Mountains. Most probably, discontinuous 
permafrost existed here with taliks below valley glaciers. Under present-day climate, the Nizke Tatry Mountains are free of any glaciers.

We received the first report of a minor presence of secondary cave carbonate precipitates similar to CCC in caves of the Dumbier area in 2004 (J. Bruthans and M. Sluka, personal communication). The new CCC locality described in this study was discovered during a regional field survey of caves in 2006 (Orvošová \& Žák, 2007).

\section{Geography and geology of the D̃umbier Karst}

Detailed descriptions of the geography and geology of the study area, together with descriptions of karst features, are contained in numerous papers, published mostly in the Slovak language in the regional literature (e.g., Louček, 1956; Kubiny, 1961; Biely et al., 1992; Bella, 1994; Biely \& Bezák, 1997; Štéc, 2000; Zelinka, 2003; Bella, 2004). The EastWest tectonic slice of sediments mentioned above is bordered by granitic rocks from the North and by granitic and metamorphic rocks from the South. This highly compressed unit consists of Lower Triassic quartzite and shale (Werfenian = Lower Scythian = Induan in the international scale), pink-colored and cellular dolomitic limestone, endostratic limestone breccia (Werfenian), dark-grey limestone (Guttenstein type), yellow-gray to yellow dolomite and vermicular grey limestone (Anisian).

The limestone strata dip is very steep, even vertical in places, in the section where most caves are developed. The tectonic structure of the whole sedimentary unit is complex, consisting of several tectonic slices, locally with brachyanticlinal or brachysynclical internal structure. At the northern edge, the granitic rocks overthrust the sediments along a regional fault, which is steeply sloped to the north (Fig 1). The tectonic structure is further complicated by younger (probably Miocene) strike faults, and steep N-S faults. At several places (and well visible in the caves as well) the Triassic sediments were intruded by basaltic magmatic dyke rocks with amygdaloidal texture for which Early Cretaceous age has been proposed (Hovorka \& Spišiak, 1988). M. Sluka (personal communication, 2004) based on shapes of these intrusions considered a possibility that these magmatic rocks occasionally intruded some existing karst cavities, which is a feature known to exist in the Alps (Rossi \& Zorzin, 1993). Nevertheless, no detailed survey of the morphology of these magmatic dykes was done.

The current morphology of the Western Carpathians is largely influenced by a history of uneven uplift of individual blocks, especially during the Neogene (in the traditional meaning) and Pleistocene. It is usually speculated that the Nizke Tatry Mts. did not yet form a pronounced mountain range during the Paleogene. Nevertheless, they were most probably not covered by Paleogene molasse sedimentation and were therefore subjected to erosion and karstification. The presentday arc-horst structure of the Nizke Tatry Mts. was formed by differential uplift during the Neogene and Pleistocene (Biely et al., 1992).
This morphological evolution of the Western Carpathians in Slovakia can be seen today in leveled surfaces, present mostly at elevations between 600 and $1,100 \mathrm{~m}$ a. s. 1 , and mostly occurring several tens of $\mathrm{km} \mathrm{E}$ and $\mathrm{SE}$ of the studied Nizke Tatry Mts. The age of these leveled plains has been widely discussed in the local literature (reviewed by Jakál, 2005). The highest of these leveled surfaces, the socalled Middle Mountain Level, is usually interpreted as pediment of Sarmatian-Pannonian or Pannonian age (for relationships between regional stages and international chronostratigraphy see Harzhauser \& Piller, 2007; Harzhauser \& Mandic, 2008). This originally uniform leveled surface was dissected by uneven uplift and erosion. Practically all caves in the studied area are located above this Middle Mountain Level, including widespread sub-horizontal waterlevel controlled cave corridors. This cave positioning can be interpreted either as a result of larger uplift in the central part of the Nizke Tatry Mts., or as a result of the considerable age of the caves, or both. This question of the possible pre-Quaternary age of some Western Carpathians caves was already discussed by Hochmuth (1998).

For the formation of caves in the studied area close to Dumbier Mt. the most important factor was the very steep dip in limestone strata located adjacent to nonkarstic rocks, and the significant disturbance of these limestones by longitudinal faults (Bella, 2004). Some papers have even considered the possibility of the existence of tectonic, non-karstic cavities along these faults (Bella, 1994). Based on present-day knowledge, the most extensive caves occur below the ridge of Kozie Chrbty, including the Jaskyña Mŕtvych Netopierov (JMN), meaning "Dead Bats Cave", and below the eastern part of the wide mountain gap located east of Ďumbier Mt., including the Jaskyña Studeného Vetra (JSV), meaning "Cold Wind Cave" (see Figs. 1 and 2).

\section{A history of the cave discoveries}

Most caves in this region have been discovered since 1981 by members of the Slovak Speleological Society, with the participation of several Czech and some UK cavers. The history of discoveries is contained in numerous local papers (e. g., Chudik, 1925-1926; Louček, 1956; Kubiny, 1961; Jirmer, 1981; Štéc, 1986, 1987; Budaj et al., 1997; Štéc, 1997, 1998; Budaj \& Mudrák, 1999; Štéc, 2000, 2001; Bella, 2004; Štéc \& Budaj, 2005).

The first information about the existence of caves in the area is several hundred years old, but the first maps of cave sections located close to the surface were done by Chudik (1925-1926), including the entrance section of the JMN Cave. A systematic cave survey was done in 1958 by a group of professional cavers from the state enterprise Turista (led by J. Majko), when searching the area for a cave suitable for tourist access. During this survey 21 small caves were mapped, and the entrance section of the JMN Cave was named. The first break-through discovery in this cave occurred on 27 September 1981, when J. Petko, 


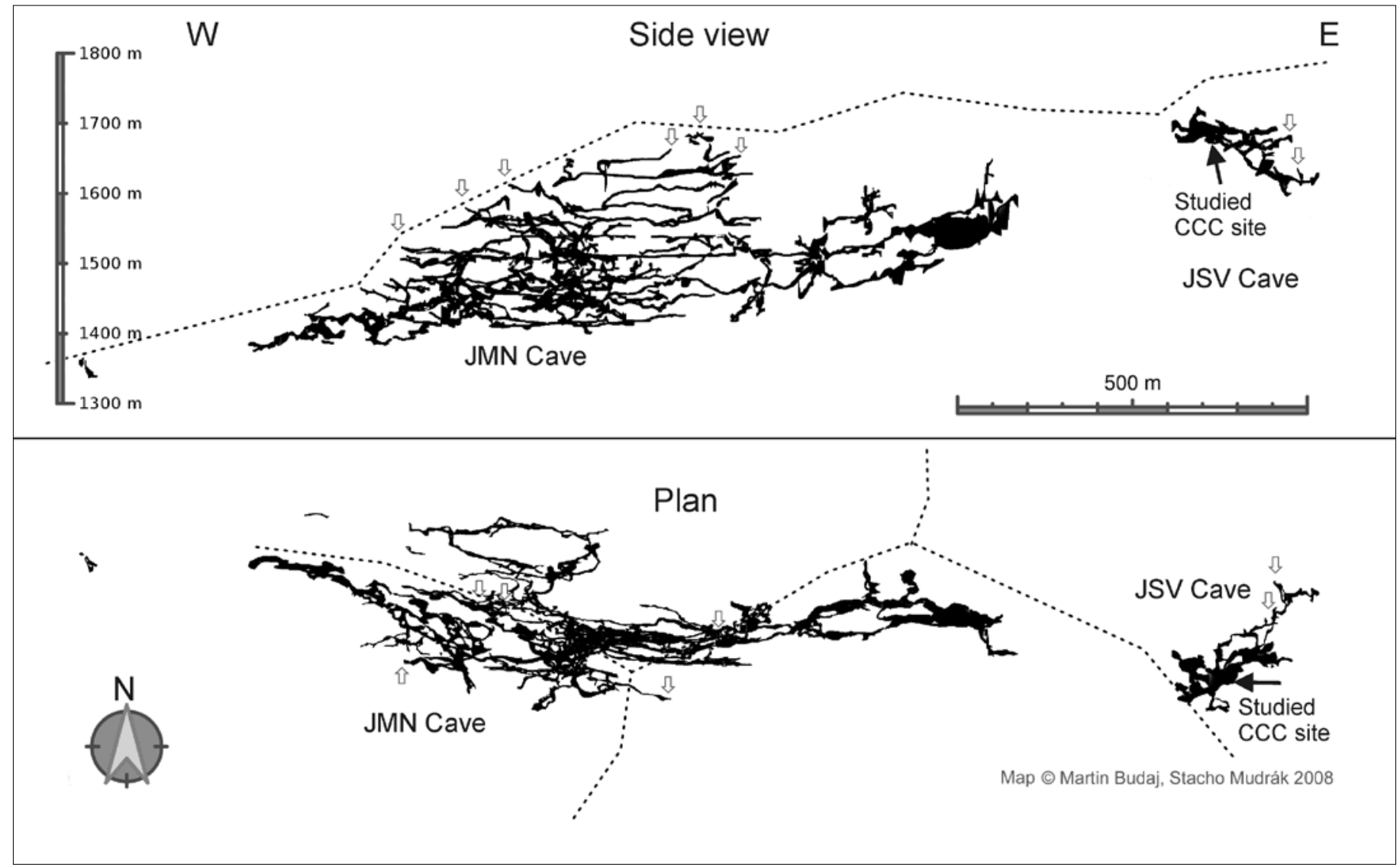

Fig. 2. Projected profile (side view, upper part of the figure) and plan view (lower part of the figure) of the JMN and JSV Caves. Projection of mountain ridges is show by a dashed line. Empty arrows indicate cave entrances. Full arrow indicates the studied CCC site in the JSV Cave. Surveyed by M. Štéc, M. Sluka, Š. Mlynárik, M. Budaj, S. Mudrák, R. Magáň, J. Szunyog and members of Slovak and Czech Speleological Societies. Data processing M. Budaj and S. Mudrák in Therion (http://therion.speleo.sk).

I. Schóber and M. Štéc penetrated through a collapsed roof section into an extensive cave system. By the end of 1982, the total known cave length was $2.5 \mathrm{~km}$ with depths down to $-223 \mathrm{~m}$ below the discovery entrance (Štéc, 2000).

Further prospecting of the JMN Cave has been a long-term process, due to the unusual morphological complexity of the cave, numerous roof collapses blocking corridors, and the need to climb up numerous chimneys. Nevertheless, the length of the known part of the cave continued to grow (more than $3 \mathrm{~km}$ of length in 1986 and a new entrance was opened on the eastern side of the cave; the highest point +77 $\mathrm{m}$ above the discovery entrance was reached in 1987 and another new entrance was opened on western cave side at the most common horizontal level of 1,510-1,520 $\mathrm{m}$ a. s. 1.; new discoveries in the eastern part of the cave were made in 1988 together with the large Bystrica Dome, discovered in 1989). Most efforts in the early 1990s were devoted to opening part of the cave to tourists (opened on 2 August 1996). Subsequent detailed mapping (Budaj et al., 1997) and new discoveries extended the known length to more than $12 \mathrm{~km}$, and the vertical extent to $300 \mathrm{~m}$. Since 2004, exploration has concentrated on the deepest cave section and its continuation in the western direction (Štéc \& Budaj, 2005). As of today, the length of the JMN Cave is $19,260 \mathrm{~m}$ with a vertical extent of $320 \mathrm{~m}$ (Tencer, 2008a, 2008b). The active cave level, with main current drainage to the $\mathrm{W}$, has not yet been discovered, but it is certainly not much deeper than the presently known deepest cave parts.

The entrance of the JSV Cave was discovered by M. Kováčik, S. Mudrák, P. Sedlák, and M. Štéc during speleological mapping on 24 July 1998 (Štéc, 1998). The discovery of large halls located at shallow depths below the surface in 1999 (by climbing up chimneys with collapsed sections) was followed by the opening of a new entrance at a higher elevation. The cave length reached $1,518 \mathrm{~m}$ with a vertical extent of $107 \mathrm{~m}(1,607$ 1,714 m a. s. 1.; Budaj \& Mudrák, 1999). Subsequent minor discoveries enlarged the cave to $1,779 \mathrm{~m}$ long and $129 \mathrm{~m}$ vertical extent (Tencer, 2008a, 2008b). A map and longitudinal projection of the whole JMNJSV Cave System are shown in Fig. 2.

\section{Cave morphology and opinions on cave genesis}

In mountain units that experienced significant uplift, and where practically all older morphological phenomena were erased as the result of Pleistocene erosion and glacial processes, caves can be the only environment that conserve information about geomorphologic development during pre-Quaternary periods (Audra et al., 2006). The morphology of caves and their sedimentary fill can provide geomorphologic information about conditions during their formation, even when such information is lost on the surface. The JMN and JSV Caves represent such a case.

Both the JMN and JSV Caves are parts of an originally interconnected cave system, interrupted (or 
at least strongly affected) by the headward erosion of the Mlynná Valley from the south, Bystrá Valley from the west, and Štiavnica Valley from the NE (Figs. 1, 2). Because of the greater extent, cave morphology and characteristic origin features are better seen in the JMN Cave. Evaluations of cave morphology in relation to host-rock lithology, tectonic structure, and cave paleohydrology and recent hydrology have been done by Bella (1994), Štéc (2000), Bruthans (2004), Bella (2004) and Štéc \& Budaj (2005). It is clear that the JMN Cave represents a case where cave morphology and cave sediments are the only evidence of the pre-Quaternary morphology of the area, with any relics of pre-Quaternary geomorphology having been completely destroyed by Pleistocene glacial processes and erosion at the surface.

The JMN Cave is characterized by numerous subhorizontal cave levels, frequently of monumental, tunnel-like development, supplemented by abundant phreatic loops and phreatic maze sections resulting from injection of floodwaters. This system of horizontal cave levels is crosscut by abundant steep to vertical vadose chimneys and channels, usually of much smaller diameter.

Up to 14 sub-horizontal cave levels have traditionally been described, some of which are quite evident and well developed, while some, especially in the deeper part of the cave, are less obvious. Phreatic loops and phreatic maze sections are more abundant in the deeper part. The most evident sub-horizontal, waterlevel controlled cave horizons, which are typical for the upper cave part, developed from initial epiphreatic channels to almost horizontal, water-level controlled corridors, with fluvial transport of abundant allochthonous (non-karstic) clastic material. Gravels with typical pebble size between 3 and $7 \mathrm{~cm}$ are characterized by a dominance of well-rounded pebbles formed from silicate rocks and quartz. Well-sorted quartz-dominated sands with rounded grains occur as well (Orvošová et al., 2006). Paleomagnetic studies indicate that these sediments are older than $3.5 \mathrm{Ma}$ (Kadlec et al., 2004). These clastic allochthonous sediments occasionally form distinct terraces along the walls of cave corridors. The best developed horizontal levels are those at 1,510-1,520 m a. s. 1., and at 1,560 $\mathrm{m}$ a. s. 1. The formation of these sub-horizontal cave levels was controlled either by climatic changes, slow gradual uplift, or both.

Meander notches undercut the steeply dipping limestone strata at many places, and sections subsequently collapsed into the corridors. The central part of the roof therefore has morphology defined by corrosion, while the morphology of other parts of the corridor is often defined by collapses. During the formation of deeper cave levels, vadose processes frequently overdeepened the central parts of higher corridors, and the sediments were transported to deeper levels.

Because of steep stream gradients, present-day surface water streams of the Nizke Tatry Mountains do not contain or transport clastic material of similar grain size and roundness as the fluvial sedimentary material deposited in sub-horizontal cave levels. This indicates that these cave parts were formed under different surface morphology than at present, in a landscape with much smaller vertical differences (cf. Audra et al., 2006). The dimensions of some conduits are very large when compared with the present catchment area, thus providing evidence that older catchment areas feeding these conduits were much larger. Underground streams transported clastic material derived from these large, non-karstic watersheds through the cave. These cave section were therefore formed before the main uplift of the central part of the Nizke Tatry Mts. (see Bruthans, 2004; Bella, 2004, for more detailed discussions).

Vertical and steep vadose shafts were formed during subsequent cave development, accompanied locally by the removal of older sediments. At some places, several levels were interconnected by vertical cavities, thus forming deep canyons (e.g. the Canyon at the beginning of the tourist loop, Budaj et al., 1997). Present-day drainage of the cave is directed to the W.

Roof and rock collapses are widespread in the whole JMN-JSV cave system. They are quite abundant in large halls of the eastern parts of the JMN Cave and in big halls of the JSV Cave (Fig. 2). Rock collapses are influenced by fault structures in both longitudinal and transversal directions. Bella (1994) concluded that some cavities could have been formed by tectonic instead of karstic processes. Bruthans (2004) even speculated that some of the large domes resulted from Quaternary slope movements. The condition of cave corridors influenced by Late-Alpine tectonic movements is well known from the Alps (Uggeri, 1992). Nevertheless, most rock collapses in the system are related to frost shattering during Quaternary glaciations. This process was most important in sections located close to cave entrances and in larger halls located at shallow depths below the surface (Štéc 2000).

\section{Present-day cave climatology}

Climatic conditions at the surface above the cave system are controlled by elevation. Mean annual air temperature is $+0.8{ }^{\circ} \mathrm{C}$ (January and February air temperature average about $-7{ }^{\circ} \mathrm{C}$; July and August average about $+8{ }^{\circ} \mathrm{C}$ ), and annual total precipitation averages $1,328 \mathrm{~mm}$ in the wide mountain gap east of Ďumbier Mt. (gap situated at 1,740 m a. s. 1.; Štéc, 2000; Zelinka, 2003).

In the JSV Cave, no long-term air temperature measurements have been performed, though the air temperature most probably slightly oscillates around to $4{ }^{\circ} \mathrm{C}$ in the main cave domes where the $\mathrm{CCC}$ have been discovered (J. Zelinka, personal communication). A local growth of cave ice near the lower cave entrance of the JSV Cave was described by Štéc (2001). This entrance acts as air input site during winter and accumulates snow from the surface. The main domes with the studied CCC occurrences certainly do not have freezing temperatures under present-day conditions.

In the JMN Cave, detailed climatic measurements 
were performed at 17 sites between 1985 and 1986 (Štéc, 1987), and again before the cave was opened to tourists (Štéc, 1997). The climatic conditions of both caves are determined by the fact that the whole JMNJSV cave system (though presently not interconnected) has more than 20 openings located at a wide range of elevations. The air circulates through these openings (including some sites covered by surface talus accumulations) depending on temperature (density) differences as well as outside wind direction. The average air temperature of the JMN Cave sections more distant from the entrances is slightly above $3{ }^{\circ} \mathrm{C}$ and shows only very small oscillations of temperature. Sections located closer to entrances generally show larger temperature variability, including temperatures below freezing near those entrances which act as air input sites during winter.

The air flow rates in the cave are quite dynamic, frequently above $2 \mathrm{~m} \cdot \mathrm{s}^{-1}$ in some narrower cave profiles, and occasionally up to $7 \mathrm{~m} \cdot \mathrm{s}^{-1}$. Because of this rapid air flow, snow can accumulate even at sites located several tens of meters inside the cave (Kozí Hall in JMN Cave; all climatic data are derived from Štéc, 1987, $1997,2000)$. In sections of the JMN Cave where the air temperature drops below freezing, the usual types of ice decoration are formed from drip waters. Finegrained (powder) CCC precipitates can sometimes be found associated with these seasonally formed present-day ice formations, similar to fine-grained CCCs known from many caves with occurrence of the cave ice (see Žák et al., 2004, 2008, for a review; see also Spötl, 2008). These modern fine-grained CCCs were not considered in this study. Periodic freezing conditions in some parts of the JMN Cave could have been the cause of frequent bat deaths during hibernation. Abundant layers of bat bones, dating back to $6 \mathrm{ka}$, give the cave its name (Štéc 2000).

\section{COARSE-GRAINED CRYOGENIC CARBONATES IN THE JSV CAVE}

Accumulations of coarse-grained CCC precipitates were found in JSV Cave at several locations within the largest cave chamber called Petra Duranu Dome (Fig. 2). This large cavity (length about $80 \mathrm{~m}$, width up to 40 $\mathrm{m})$ with an inclined floor covered by limestone blocks is located only few tens of meters below the surface. Some chimneys reach a level of just $15 \mathrm{~m}$ below the surface. Nevertheless, none of these chimneys is presently open to the surface. A fault zone on its SE side borders the whole cavity and its morphology is influenced by extensive roof collapses.

The CCC accumulations were found at several locations on the surface of huge limestone blocks (up to $2 \times 2 \times 4 \mathrm{~m}$ ) that had fallen from the cave ceiling. The most important sites are located close to the center of the Petra Duranu Dome. The studied samples come from two localities. Locality 1 (Figs 3, 4, and 5 ) has the richest accumulations and contains CCC forms even larger than $30 \mathrm{~mm}$. This is the largest size of CCC found so far. The terminology of CCC crystal aggregates has not been fully established yet. Complete simple forms were called spherolites by
Richter \& Riechelmann (2008). Similar, hemispherical forms were called hemispherolites by Tulis \& Novotný (1989). Almost identical crystal aggregate shapes occur at all localities, confirming similar processes of their formation (see Richter \& Riechelmann, 2008, for further discussion on crystal aggregate shapes). Locality 2 (Figs. 6, 7) is characterized by a dominance

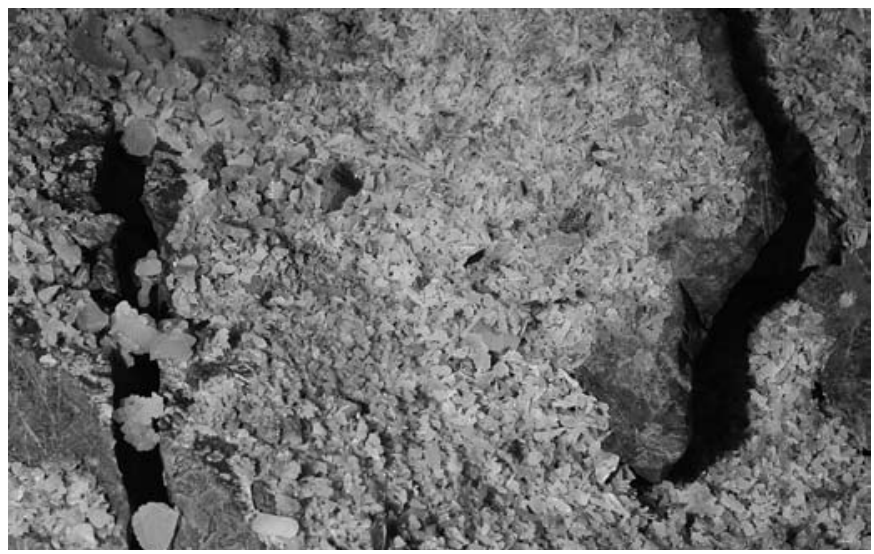

Fig. 3. Overall view of the central part of the main CCC accumulation (Locality 1) in the Petra Duranu Dome of JSV Cave. The width of the photographed area is $25 \mathrm{~cm}$. Photo by M. Majer.

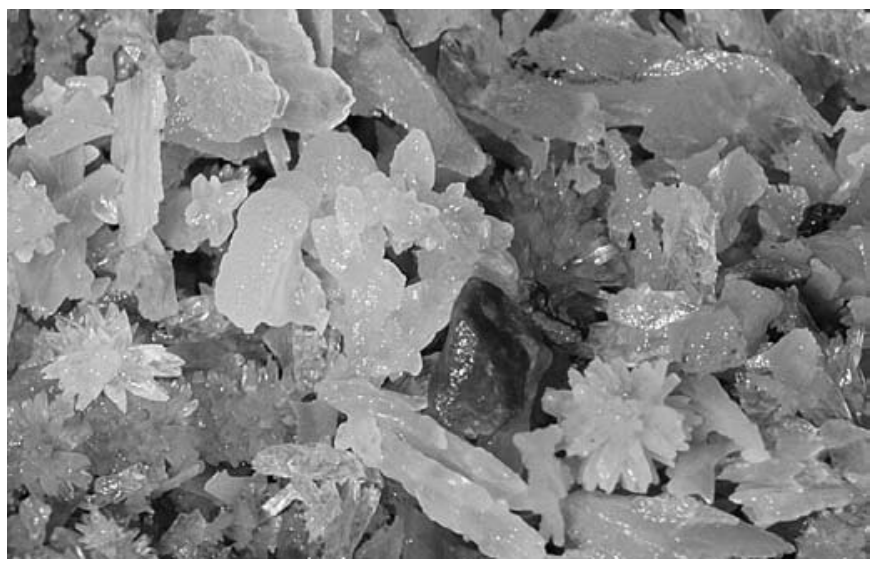

Fig. 4. Close-up view of the central part of the main CCC accumulation (Locality 1 ) in the Petra Duranu Dome of JSV Cave. The width of the photographed area is $3 \mathrm{~cm}$. Photo by M. Majer.

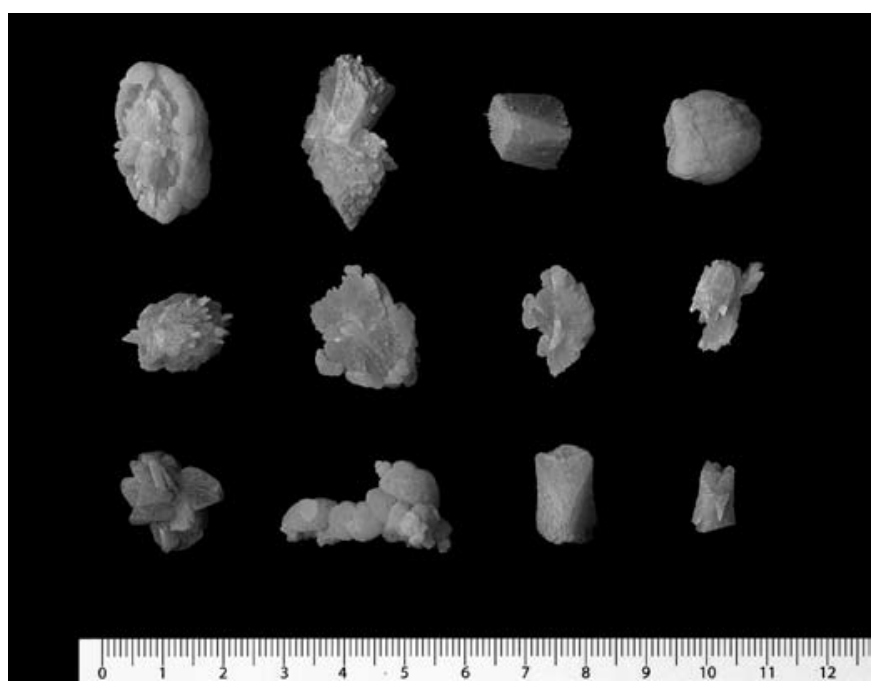

Fig. 5. Large forms of CCC from the main accumulation in the Petra Duranu Dome of JSV Cave. Scale at the figure bottom is $12 \mathrm{~cm}$. See Richter \& Riechelmann (2008) for general discussion on crystal aggregate shapes. Photo by J. Brožek. 


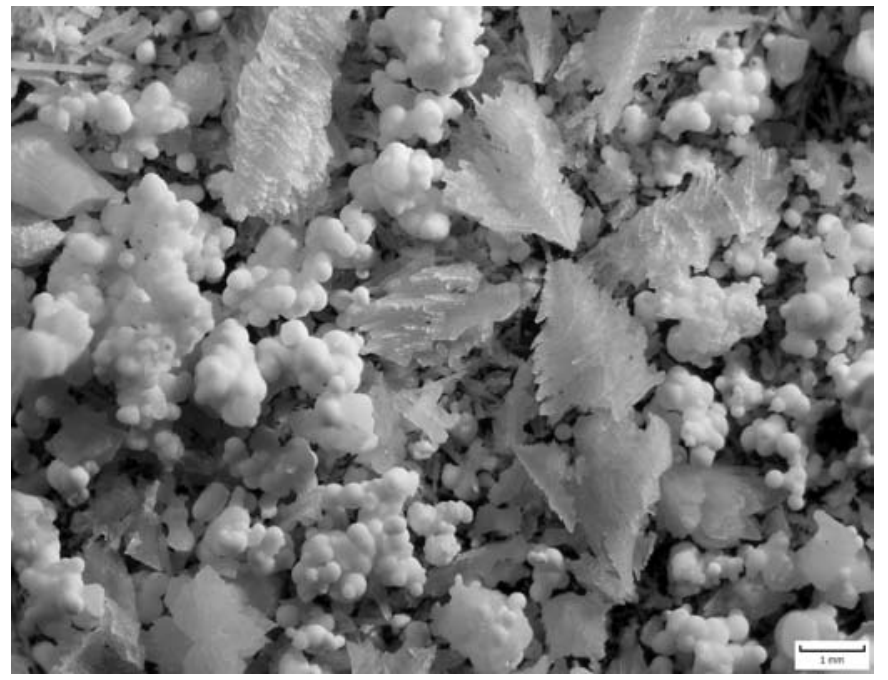

Fig. 6. CCC crystal aggreates from Locality 2 in the Petra Ďuranu Dome of JSV Cave. Microscope photo by M. Filippi, scale bar is $1 \mathrm{~mm}$.

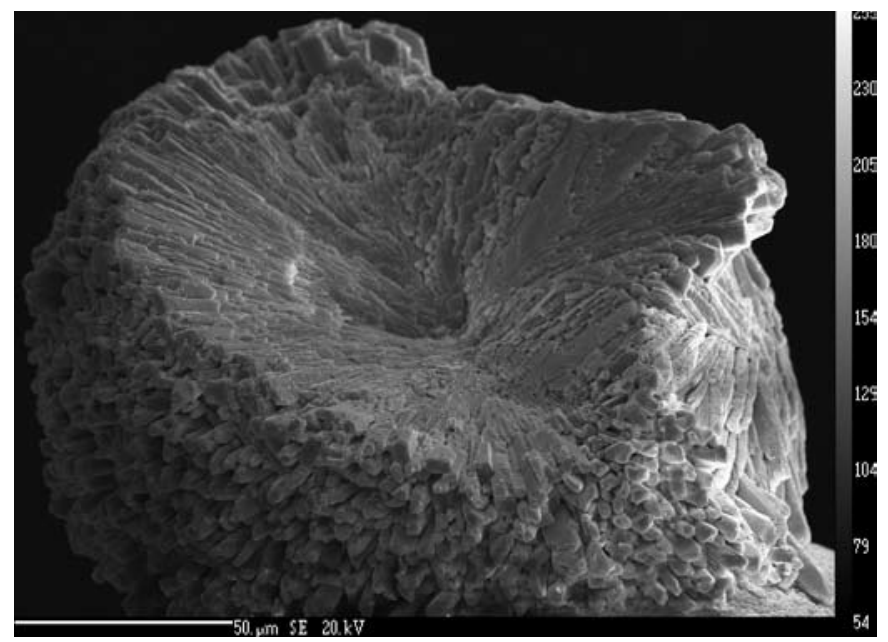

Figure 7. A detailed view of a small concretion from Locality 2 shows that it is composed of fine needle crystals. Scale bar is $50 \mu \mathrm{m}$. Cameca SX 100, secondary electrons, photo by Z. Korbelová.

of small skeletal crystals, needles and harpoon-like crystal aggregates, and small white concretions, sometimes covered by a thin clay layer. The Locality 2 is located slightly higher in the cavity than Locality 1. The fact that the main $\mathrm{CCC}$ accumulations, along with some bat bones, cover the surface of limestone blocks fallen from the cavity ceiling indicates that the formation of CCC postdates one of the most significant periods of frost shattering.

\section{METHODS}

Several typical crystal aggregates of large CCC from Locality 1 , and one composite sample of smaller crystal aggregates from Locality 2, were selected for U-series dating. The mass of grains from Locality 2 is too low to allow dating on a single grain. Standard chemical procedures for uranium and thorium separation from carbonate samples were used (Ivanovich \& Harmon, 1992). Samples were dissolved in ca. $6 \mathrm{M} \mathrm{HNO}_{3}$ and a ${ }^{228} \mathrm{Th}-{ }^{232} \mathrm{U}$ spike mixture was added to control the chemical efficiency of the procedure. After the oxidation of any organic matter using $\mathrm{H}_{2} \mathrm{O}_{2}$, the $\mathrm{U}$ and Th separation was performed using co-precipitation with iron hydroxides. After iron removal using ether extraction, $U$ and Th were separated by ion exchange using DOWEX 1x8 resin, followed by the electrodepositing of $U$ and $T h$ on steel disks. The energetic spectra of alpha particles were collected using an OCTETE PC spectrometer made by EG\&G ORTEC. Spectral analyses and age calculations were done using "URANOTHOR 2.6" software, which is standard software developed in the U-Series Laboratory in Warsaw (Gorka \& Hercman, 2002; half-lives are after Cheng et al., 2000). As a chemical procedure testing mixture ${ }^{232} \mathrm{U}-{ }^{228} \mathrm{Th}$ (UDP10030; Isotrack, AEA Technology, UK) were used. This spike was calibrated against natural uranium and ${ }^{229} \mathrm{Th}(4321 \mathrm{C}$ and $4328 \mathrm{~B}$; National Institute of Standards and Technology, USA). Blanks were measured at regular intervals and after any new batch of chemicals, as well as internal and external laboratory standards. The reported errors are 10 .

$\mathrm{C}$ and $\mathrm{O}$ stable isotope analyses followed the usual procedure of sample digestion in $100 \% \mathrm{H}_{3} \mathrm{PO}_{4}$ under vacuum, followed by measurement using a Finnigan MAT 251 Mass Spectrometer in the Laboratories of the Czech Geological Survey in Prague. Analytical uncertainty is $\pm 0.1 \%$ o for both $\delta^{13} \mathrm{C}$ and $\delta^{18} \mathrm{O}$ values.

\section{RESULTS}

The morphology of CCC crystal aggregates from the JSV Cave is similar to those described in previous studies from other caves (e.g., Durakiewicz et al., 1995; Richter \& Riechelmann, 2008) as all usual forms (skeletal crystals, irregular hemispheres, morphologically complex micro-concretions, needlelike crystals, etc.) were observed. Therefore, additional grain morphology is not discussed in detail here. The most surprising was the size of individual crystal aggregates, which reached up to $35 \mathrm{~mm}$ at Locality 1 (see Fig. 3-5).

Results of the CCC U-series dating are shown in Table 1. The two dated samples from Locality 1 yielded ages from the first half of the Weichselian $(79.7 \pm 2.3$ and $104.0 \pm 2.9 \mathrm{ka}$ ), and are therefore significantly older than Weichselian CCC samples dated so far from caves in Poland, Slovakia, the Czech Republic and Germany (Žák et al., 2004; Richter \& Riechelmann, 2008). The sample from Locality 2 yielded significantly higher age corresponding to the Saalian glaciation $(180.0 \pm 6.3 \mathrm{ka})$. In most cases, the calculated $\mathrm{Th} / \mathrm{U}$ ages correspond to interstadial substages, i.e. a warmer interval within a glaciation period.

Results of the stable isotope analyses are shown in Tab. 2 and Fig. 8. In a $\delta^{13} \mathrm{C}$ vs. $\delta^{18} \mathrm{O}$ diagram, the CCC from the JSV Cave is characterized by high $\delta^{13} \mathrm{C}$ values (up to $6.34 \%$ ), and by very low carbonate $\delta^{18} \mathrm{O}$ values (down to $-22.61 \%$ V-PDB). Locality 1 and Locality 2 data slightly differ in $\delta^{18} \mathrm{O}$, with Locality 2 characterized by lower $\delta^{18} \mathrm{O}$ values. However, the $\delta^{13} \mathrm{C}$ and $\delta^{18} \mathrm{O}$ data from both localities show a negative relation, increase in $\delta^{13} \mathrm{C}$ is accompanied by decrease in the $\delta^{18} \mathrm{O}$.

\section{DISCUSSION}

The carbon and oxygen isotope data of the coarse- 
Table 1. Results of ${ }^{230} \mathrm{Th} / 234 \mathrm{U}$ dating of the CCC samples. $A R=$ activity ratio. Errors are $1 \sigma$.

\begin{tabular}{|c|c|c|c|c|c|c|}
\hline Sample number, location, and description & Lab. No. & $\begin{array}{c}\text { U cont. } \\
\text { [ppm] }\end{array}$ & $\begin{array}{c}{ }^{234} \mathrm{U} /{ }^{238} \mathrm{U} \\
{[\mathrm{AR}]}\end{array}$ & $\begin{array}{c}{ }^{230} \mathrm{Th} /{ }^{234} \mathrm{U} \\
{[\mathrm{AR}]}\end{array}$ & $\begin{array}{c}{ }^{230} \mathrm{Th} /{ }^{232} \mathrm{Th} \\
{[\mathrm{AR}]}\end{array}$ & $\begin{array}{c}\text { Age } \\
{[\mathrm{ka}]}\end{array}$ \\
\hline $\begin{array}{c}\text { JSV-1/1, JSV Cave, Locality 1, several } \\
\text { hemispheres }\end{array}$ & $\mathrm{W} 1896$ & $2.10 \pm 0.06$ & $1.53 \pm 0.0301$ & $0.539 \pm 0.011$ & $448 \pm 166$ & $\mathbf{7 9 . 7}$ \\
\hline $\begin{array}{c}\text { JSV-1/2, JSV Cave, Locality 1, two large } \\
\text { crystals (intergrowth) }\end{array}$ & $\mathrm{W} 2155$ & $1.48 \pm 0.03$ & $1.58 \pm 0.03$ & $0.659 \pm 0.010$ & $50 \pm 5$ & $\mathbf{1 0 4 . 0 _ { - 2 . 8 } ^ { + 2 . 9 }}$ \\
\hline $\begin{array}{c}\text { JSV-2, JSV Cave, Locality 2, accumulation of } \\
\text { fine-grained crystals and concretions }\end{array}$ & $\mathrm{W} 2156$ & $0.57 \pm 0.01$ & $1.62 \pm 0.03$ & $0.880 \pm 0.020$ & $69 \pm 8$ & $\mathbf{1 8 0 . 0 _ { - 6 . 0 } ^ { + 6 . 3 }}$ \\
\hline
\end{tabular}

Table 2. Results of $\mathrm{C}$ and $\mathrm{O}$ isotope analyses from CCC samples. Overall analytical uncertainty is $\pm 0.1 \%$ for both $\delta 1^{3} \mathrm{C}$ and $\delta^{18} \mathrm{O}$.

\begin{tabular}{|c|c|c|}
\hline Sample number, location, and description & $\begin{array}{c}\delta^{13} \mathrm{C} \\
(\%, \mathrm{~V}-\mathrm{PDB})\end{array}$ & $\begin{array}{c}\delta^{18} \mathrm{O} \\
(\%, \mathrm{~V}-\mathrm{PDB})\end{array}$ \\
\hline JSV1, Locality 1 , in the eastern part of the accumulation, small crystals, locally skeletal & 0.72 & -13.68 \\
\hline $\begin{array}{l}\text { JSV2, Locality } 2 \text {, accumulation of small crystals and concretions, partly covered by a clay layer, this } \\
\text { sample - small white concretions }\end{array}$ & 6.34 & -22.61 \\
\hline $\begin{array}{l}\text { JSV3, Locality 2, selected more massive milky grains, some look like hemispheres or crystals with } \\
\text { extended corners }\end{array}$ & 5.36 & -21.78 \\
\hline JSV4, Locality 2, needle-like crystals & 4.94 & -21.54 \\
\hline JSV5, Locality 1 , complex crystal intergrowth & 2.69 & -14.98 \\
\hline JSV6, Locality 1 , one $6 \mathrm{~mm}$ large crystal & 4.44 & -18.33 \\
\hline JSV7, Locality 1, irregular hemisphere & 5.00 & -18.84 \\
\hline $\begin{array}{l}\text { JSV8, Locality } 1 \text {, irregular hemisphere (upper right corner on Fig. } 5 \text { ), height } 14 \mathrm{~mm} \text {, profile base to top, } \\
\text { sampling step equals } 2 \mathrm{~mm} \text {, this sample } 0 \text { to } 2 \mathrm{~mm}\end{array}$ & 4.86 & -18.61 \\
\hline JSV9, the same profile, 2 to $4 \mathrm{~mm}$ from base & 4.60 & -18.45 \\
\hline JSV10, the same profile, 4 to $6 \mathrm{~mm}$ from base & 4.48 & -18.44 \\
\hline JSV11, the same profile, 6 to $8 \mathrm{~mm}$ from base & 4.53 & -18.43 \\
\hline JSV12, the same profile, 8 to $10 \mathrm{~mm}$ from base & 4.61 & -18.61 \\
\hline JSV13, the same profile, 10 to $12 \mathrm{~mm}$ from base & 4.77 & -18.77 \\
\hline JSV14, the same profile, 12 to $14 \mathrm{~mm}$ from base, hemisphere top & 4.91 & -18.82 \\
\hline $\begin{array}{l}\text { JSV15, Locality } 2 \text {, separated small white concretions, size } 0.1 \text { to } 0.5 \mathrm{~mm} \text {, locally forming assemblages } \\
\text { of concretions }\end{array}$ & 6.16 & -22.47 \\
\hline JSV16, Locality 2, skeletal crystal of "envelope shape", base $4 \times 3 \mathrm{~mm}$, height $3 \mathrm{~mm}$ & 3.73 & -17.13 \\
\hline JSV17, Locality 2, small needles and harpoon-like crystals, length up to $2 \mathrm{~mm}$ & 4.82 & -21.11 \\
\hline JSV18, Locality 1, part of a bigger (12 mm across) rosette (lower left corner on Fig. 5) & 3.49 & -16.39 \\
\hline
\end{tabular}

grained CCC precipitates from the JSV Cave lie in an area of the $\delta^{18} \mathrm{O}$ vs. $\delta^{13} \mathrm{C}$ plot where other speleothem types are rarely present. Majority of usual speleothems (stalactites, stalagmites, flowstones, etc.) of Middle and Upper Pleistocene age were formed in the study area during interglacials, and their formation was largely inhibited during glacials. These usual speleothems, when formed under, or close to, the isotope equilibrium among water, aqueous species and calcite, plot to a relatively restricted area in the $\delta^{18} \mathrm{O}$ vs. $\delta^{13} \mathrm{C}$ plot (see Fig. 8). Speleothems formed under the dominance of kinetic isotope fractionations (rapid precipitation, sometimes accompanied by water evaporation) usually show simultaneous increase in both $\delta^{18} \mathrm{O}$ and $\delta^{13} \mathrm{C}$ values (Hendy, 1971; see recent review of Lachniet, 2009). Speleothems showing slightly lower $\delta^{18} \mathrm{O}$ values than the rectangle shown in Fig. 8 were reported from Early Pleistocene of the Northern Calcareous Alps by Meyer et al. (2009) recently. This probably results from high altitude of the recharge area. Nevertheless, none of these speleothems have the $\delta^{18} \mathrm{O}$ values below -15 $\%$, which are values typical for coarse-grained CCC.
The values of CCC from the JSV Cave show a negative relation, with the lower $\delta^{18} \mathrm{O}$ values accompanied by higher $\delta^{13} \mathrm{C}$. This relation is typical for samples from all coarse-grained CCC precipitates studied so far (Fig. 8). These trends have been interpreted as the result of two isotope fractionation mechanisms operating simultaneously: the incorporation of the heavier ${ }^{18} \mathrm{O}$ isotope into formed ice resulting in a shift towards more negative $\delta^{18} \mathrm{O}$ values in the residual aqueous solution (e.g., Souchez \& Jouzel, 1984), and the simultaneous escape of $\mathrm{CO}_{2}$ with lower $\delta^{13} \mathrm{C}$ values from the solution (and eventually from the whole cave system) resulting in a shift to higher bicarbonate $\delta^{13} \mathrm{C}$ values in the residual solution (Žák et al., 2004). The $\delta^{18} \mathrm{O}$ data from Locality 1 and Locality 2 within the JSV Cave are shifted, with Locality 2 characterized by a significantly lower $\delta^{18} \mathrm{O}$ range. This could either be the result of a lower dissolved load of waters forming Locality 2 (a larger proportion of water had to be frozen before reaching carbonate saturation, cf. Lacelle et al., 2006), or the result of lower $\delta^{18} \mathrm{O}$ in the precipitation (rainfall/snow) falling above the cave 


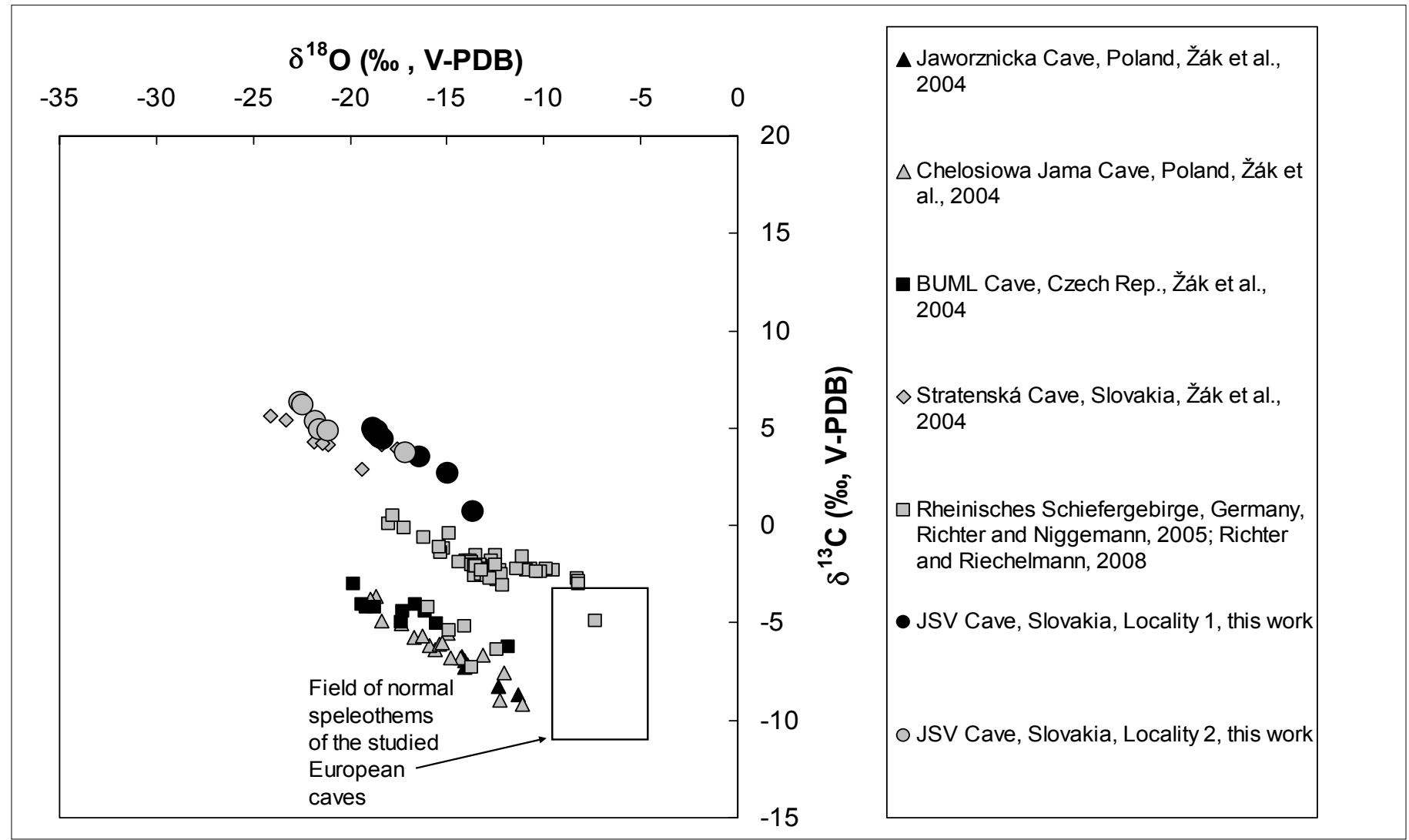

Fig. 8. Stable isotope data of studied CCC compared to data of other known coarse-grained CCC from central European caves. The field of stable isotope composition of normal speleothem of the central European caves represents typical compositions of Middle and Upper Pleistocene speleothems formed under (or close to) isotope equilibrium during warm climatic phases, mostly interglacials.

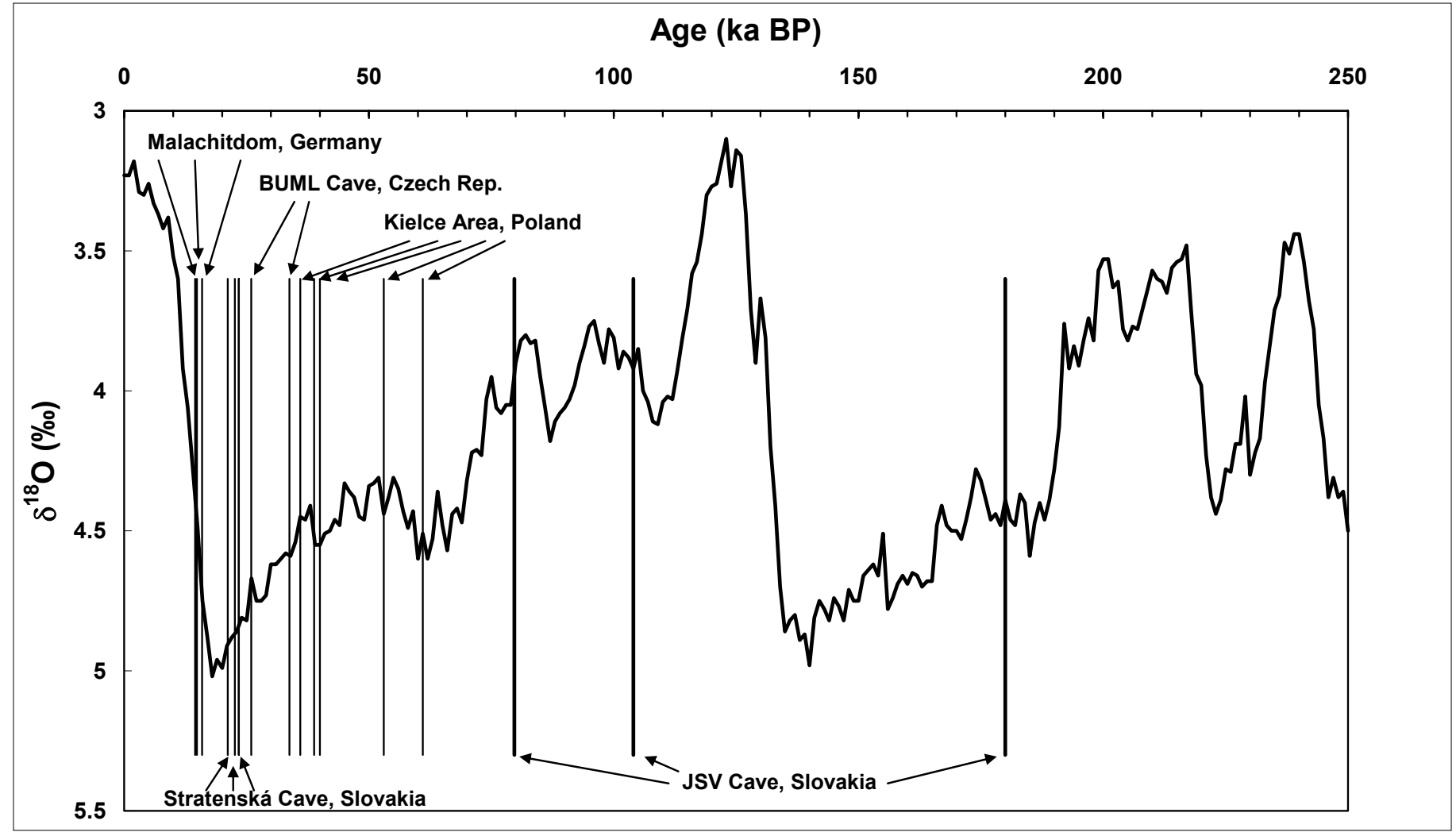

Figure 9. Ages of CCC shown against the curve of $\delta^{18} \mathrm{O}$ of benthic foraminifers by Lisiecki \& Raymo (2005). CCC ages are shown as vertical lines without analytical errors. Analytical errors of CCC ages are generally of \pm 2 ka or lower, with the exception of the oldest samples, for which errors can be found in Table 1.

during the Saalian glacial relative to the Weichselian.

In contrast to usual speleothems, the $\delta^{18} \mathrm{O}$ values of the CCC probably do not carry useful paleoclimatic information. Before the onset of the $\mathrm{CCC}$ precipitation, an unknown portion of water was incorporated into ice, which shifted the $\delta^{18} \mathrm{O}$ of the yet unfrozen solution 
to lower values. Since the dissolved load of the water could vary over a wide range, also the proportion of water removed to ice before the onset of carbonate precipitation can be variable, and paleoclimatic information is probably lost.

When compared to coarse-grained CCC precipitates from other Central European localities, the JSV Cave samples showed the highest $\delta^{13} \mathrm{C}$ values, similar to those of the Stratenská Cave, Slovakia (Fig. 8). This results either from higher $\delta^{13} \mathrm{C}$ of the $\mathrm{HCO}_{3}-$ of the water feeding the cave, or from specific carbon isotope fractionation within the cave. In high-altitude catchments with limited soil cover, the influence of soil $\mathrm{CO}_{2}$ may be weaker. Meyer et al. (2009) mentioned subrecent speleothems from the Entrische Kirche Cave, located $56 \mathrm{~km}$ south of Salzburg, Austria, in an inner-alpine setting. The cave has its recharge area at approximately $1900 \mathrm{~m}$ a. s. 1., and is located below a very thick rock overburden. Flowstones of this cave show $\delta^{18} \mathrm{O}$ values of $-10.2 \pm 0.4 \%$, but very high $\delta^{13} \mathrm{C}$ data between -2.5 and $-0.5 \%$. The second possible explanation for the differences in individual $\delta^{13} \mathrm{C}$ trends of $\mathrm{CCC}$ is the openness of the cave environment leading to the escape of $\mathrm{CO}_{2}$ out of the system. In caves in massive limestones located deeper below the surface and open to the surface only through narrow and sinuous corridors (which could have been blocked by ice under glacial conditions), $\mathrm{CO}_{2}$ released from freezing solutions could have remained in the cave atmosphere and re-equilibrated with the residual solution, behaving more-or-less as a closed system. This would result in $\delta^{13} \mathrm{C}$ data of coarse-grained CCC more similar to the usual, equilibrium-type speleothems. In contrast, extensive caves with large open spaces located close to surface, and open to the surface through several entrances (like JSV Cave), certainly were well connected to the outside atmosphere even under the glacial conditions, and $\delta^{13} \mathrm{C}$ would have been controlled by Rayleigh-type fractionation (with isotopically lighter $\mathrm{CO}_{2}$ escaping) resulting in generally higher $\delta^{13} \mathrm{C}$ in the formed carbonate phases. From all coarse-grained CCC localities known so far, the JSV site is located closest to the surface, in a large, well-ventilated cavity, and it also shows the highest $\delta^{13} \mathrm{C} \mathrm{CCC}$ values.

The U-series ages ranging between $79.7 \pm 2.3$ and $180.0 \pm 6.3$ in samples from the JSV Cave are the highest obtained so far for CCC from the Central European region. The ages correspond to the Early Weichselian, and to the later period of the complex Saalian glaciation. The existence of CCC is interpreted here as a proof of water freezing in the cave. The cave air (and rock) temperatures probably oscillated below and above the $0{ }^{\circ} \mathrm{C}$ isotherm several times during the Saalian and Weichselian. This higher age of CCC in the JSV Cave, when compared to the other known Weichselian localities, is probably a result of the higher elevation of the JSV Cave, the shallow depth below the surface, and the partial location below a northoriented mountain slope. The permafrost conditions could have been reached here earlier than at the other localities.
The position of the older Locality 2 is higher along the cavity bottom slope, which probably indicates that the level of cave ice surface was higher during the Saalian than during the Weichselian. The older age of Locality 2 is also supported by the minor clay cover on the CCC accumulation, which is missing at the Weichselian Locality 1 . The formation of both localities during different periods is also supported by slightly different ranges of $\mathrm{C}$ and $\mathrm{O}$ isotope data (Fig. 8).

The morphology of ice formed within the caves during $\mathrm{CCC}$ formation and the exact nature of the environment are still generally unknown. Most authors have speculated that CCC precipitates were formed during short periods of surface warming, when waters entered a cavity located within the permafrost zone and became slowly frozen. According to this concept, CCC forms in pools on the ice surface, and crystal aggregates are deposited on the bottom of the cavity after ice melting (Žák et al., 2004; Richter \& Riechelmann, 2008; Richter et al., 2008). This could also possibly explain why this type of CCC usually occurs in nests located in larger cave domes, close to their central parts.

The formation of CCC clearly represents one of youngest events in the long-term development of the JSV Cave. The formation of Holocene speleothems (usual types of stalactites, stalagmites, flowstones), deposition of abundant small bones from bats which did not survived hibernation, and some minor roof collapses are the main events postdating the CCC formation.

In contrast, the early development of the JMN-JSV Cave System is neither well understood, nor precisely dated as yet. In the Northern Calcareous Alps, where uplift history and periods of cave formation have been studied in more detail (Audra et al., 2002; Audra et al., 2006), large karst plateaus are located at altitudes above $2000 \mathrm{~m}$ a. s. 1., and the large sub-horizontal cave corridors (Riesenhöhlen), located at elevations between 1600 and $1800 \mathrm{~m}$ a. s. 1., are considered to be Upper Miocene in origin. Pliocene cave levels, related to the formation of Pliocene valleys, occur at elevations between 850 and $1050 \mathrm{~m}$ a. s. 1. (Audra et al., 2002). However, the overall uplift history of the Western Carpathians is different from that of the Northern Calcareous Alps, and even individual segments of the Western Carpathians show differences in uplift history (Jakál, 2005). The development of large subhorizontal cave levels in the JMN Cave, located at elevations above $1500 \mathrm{~m}$ a. s. 1., probably dates to the Miocene. More detailed research of the sediments preserved in this cave is needed to more precisely elucidate the early history.

\section{CONCLUSIONS}

The JSV and JMN Caves are linked in origin and together represent a major cave system with multiphase development, located within a tectonic slice of Triassic sediments at high altitude within the main range of the Nizke Tatry Mts., Slovakia. The large, tunnel-like sub-horizontal corridors were formed 
during the Tertiary, under surface morphology conditions quite different from those of today. After the Late Tertiary and Early Pleistocene uplift, the development of this cave system continued with the formation of steep invasive vadose shafts and extensive roof collapses, probably related to frost shattering. The cave system was dissected by headward erosion of the Bystrá Valley into the two parts, JMN Cave and JSV Cave.

In the largest dome of the JSV Cave, several accumulations of loose, morphologically variable carbonate crystals and crystal aggregates were found, covering the surface of limestone blocks fallen from the cavity roof. The formation of these secondary cave carbonates represents one of youngest events in the multiphase cave development, clearly postdating intensive roof frost shattering. The carbonate crystals and crystal aggregates, sized from $<1 \mathrm{~mm}$ to $35 \mathrm{~mm}$, cover an area of several square meters at the largest site, in a layer up to several $\mathrm{cm}$ thick. This is typical for cryogenic cave carbonates (CCC), which was precipitated from calcium-bicarbonate solutions during slow water freezing. The cryogenic origin of these carbonate crystal aggregates was confirmed by carbon and oxygen stable isotope analyses and U-series dating. The obtained U-series ages of $79.7 \pm 2.3,104.0 \pm 2.9$, and $180.0 \pm 6.3 \mathrm{ka}$ are the oldest obtained so far for coarse-grained CCC from caves of Central Europe. These ages indicate that the formation of $\mathrm{CCC}$ in the cave occurred during two subsequent glacial periods. CCC precipitates dated to the Saalian are located higher within the cavity than those dated to the Weichselian, which was interpreted as the result of different cave ice levels in these two subsequent glacial periods.

\section{ACKNOWLEDGEMENTS}

This study was supported by research program No. AV0Z30130516 of the Institute of Geology AS $\mathrm{CR}$, Prague. The fieldwork and sampling in the Dumbier National Reserve was allowed by the local nature protection authorities within the VEGA $1 / 3057 / 06$ project. This project also partly financed the research. For the possibility to work in the caves, technical help, and important information, we would like to thank the members of Slovak Speleological Society, Speleoclub Slovakia-Bystrá, and especially to Milan Štéc and Stacho Mudrák. Technical support by members of the Czech Speleological Society (Unit 1-02 Tetin) and their help with transport of our equipment was also highly appreciated. Field photographic documentation was performed by Martin Majer. This paper benefited greatly from thorough reviews by Denis Lacelle, Pavel Bella, and one anonymous reviewer.

\section{REFERENCES}

Audra P., Bini A., Gabrovšek F., Häuselmann P., Hobléa F., Jeannin P-Y., Kunaver J., Monbaron M., Šušteršič F., Tognini P. \& Trimmel H., 2006 - Cave genesis in the Alps between the Miocene and today: a review. Zeitschrift für Geomorphologie, 50 (2): 153-176.
Audra P., Quinif Y. \& Rochette P., 2002 - The genesis of the Tennengebirge karst and caves (Salzburg, Austria). Journal of Cave and Karst Studies, 64 (3): 153-164.

Bella P., 1994 - Genetické typy jaskynných priestorov Západných Karpát. Slovenský Kras, 32: 3-22. Liptovský Mikuláš. (In Slovak).

Bella P., 2004 - Dumbiersky kras - kontaktný pruhovitý kras $v$ centrálnej časti Nizkych Tatier (Ďumbier Karst contact stripe karst in the central part of Nizke Tatry Mts.). Geomorphologia Slovaca, 4 (2): 18-29. (In Slovak with English abstract).

Biely A., Beňuška P., Bezák V., Bujnovský A., Halouzka R., Ivanička J., Kohút M., Klinec A., Lukáčik E., Maglay J., Miko O., Pulec M., Putiš M. \& Vozár J., 1992 Geological map of the Nizke Tatry Mountains, 1:50,000. Geologický ústav Dionýza Štúra, Bratislava.

Biely A. \& Bezák V., 1997 - Vysvetlivky ku geologickej mape Nizkych Tatier 1:50 000. Geologická služba SR, Bratislava, 232 p. (In Slovak).

Bruthans J., 2004 - Poznámky $k$ charakteru a vzniku Jaskyne Mrtvych netopierov (Notes to the character and origin of the Dead Bats Cave, Nizke Tatry Mts.). In: Bella P. (Ed.) - Research, Utilization and Protection of Caves 4. Slovak Caves Administration, Liptovský Mikuláš: 43-47. (In Czech with English abstract).

Budaj M., Mlynárik Š., Mudrák S. \& Schwarz J., 1997 The latest discoveries in Dead Bats Cave. Bulletin of the Slovak Speleological Society, 28 (2): 10-13. Liptovský Mikuláš.

Budaj M. \& Mudrák S., 1999 - Za studeným vetrom... Bulletin of the Slovak Speleological Society, 30 (4): 4-7. Prešov. (In Slovak).

Cheng H., Edwards R.L., Hoff J., Gallup C.D., Richards D.A. \& Asmeron Y., 2000 - The half lives of uranium234 and thorium-230. Chemical Geology, 169: 17-33.

Chudik J., 1925-1926 - Kvaplové jaskyne na D̆umbieri. Krásy Slovenska, 5 (4): 106-107. Liptovský Mikuláš. (In Slovak).

Clark I.D. \& Lauriol B., 1992 - Kinetic enrichment of stable isotopes in cryogenic calcites. Chemical Geology, 102: 217-228.

Danišîk M., Dunkl I., Kadlec J. \& Frisch W., 2005 Cooling history of Tatric basement of Nizke Tatry Mts. (Western Carpathians) inferred from apatite fission track and (U-Th)/He analysis - preliminary results. Geolines, 19: 31-32. Prague.

Droppa A., 1957 - Demänovské jaskyne. SAV, Bratislava, 289 p. (In Slovak).

Droppa A., 1966 - Untersuchungen der parallelität von Flussterrasen mit horizontalen Höhlen. In: Proceedings of 3rd International Congress of Speleology, Vienna, 5: 79-81.

Droppa A., 1973 - Prehlad preskúmaných jaskýn̆ na Slovensku. Slovenský Kras, 11: 111-157. (In Slovak).

Durakiewicz T., Hałas S., Migaszewski M. \& Urban J., 1995 - Origin of "calcite groats" in the Chelosiowa Cave near Kielce (Holy Cross Mts.) inferred from petrographic and isotopic investigations. Geological Quarterly, 39: 75-94.

Ford D. \& Williams P., 2007 - Karst hydrogeology and geomorphology. John Wiley \& Sons, Chichester, $562 \mathrm{p}$. 
Gorka P. \& Hercman H., 2002 - URANOTHOR v. 2.6. Delphi Code of calculation program and user guide. Unpublished report, Archive of Quaternary Geology Department, Institute of Geological Sciences, PAS, Warsaw.

Harzhauser M. \& Mandic O., 2008 - Neogene lake systems of Central and South-Eastern Europe: Faunal diversity, gradients and interrelations. Palaeogeography, Palaeoclimatology, Palaeoecology, 260: 417-434.

Harzhauser M. \& Piller W.E., 2007 - Benchmark data of a changing sea - Palaeogeography, Palaeobiogeography and events in the Central Paratethys during the Miocene. Palaeogeography, Palaeoclimatology, Palaeoecology, 253: 8-31.

Hendy C.H., 1971 - The isotopic geochemistry of speleothems, I. The calculation of the effects of different modes of formation an the isotope composition of speleothems and their applicability as palaeoclimatic indicators. Geochimica Cosmochimica Acta, 35: 801824

Hochmuth Z., 1998 - Predkvartérne jaskynné systémy na Slovensku a ich vztah $k$ zarovnanym pourchom. Acta Facultatis Studiorum Humanitatis et Naturae Universitatis Presoviensis, Prírodné vedy, 29, Folia geographica 1: 127-144. (In Slovak with English abstract).

Hovorka D. \& Spišiak J., 1988 - Vulkanizmus mezozoika Západných Karpát. Veda, Bratislava, 263 p. (In Slovak).

Ivanovich M. \& Harmon R.S., Eds., 1992 - Uranium Series Disequilibrium: Applications to Earth, Marine and Environmental Sciences. 2nd ed., Clarendon Press, Oxford, $910 \mathrm{p}$.

Jakál J., 2005 - Hlavné názorové smery na genézu a vek krasových plošin Západných Karpát (The principal trends in explanation of genesis and age of karstic plains in the West Carpathian Mts.). Slovenský Kras, 43: 5-15. (In Slovak with English abstract).

Jirmer F., 1981 - Objavy $v$ Kozich chrbtoch. Bulletin of the Slovak Speleological Society, 12 (4): 13-15. Liptovský Mikuláš. (In Slovak).

Kadlec J., Pruner P., Hercman H., Chadima M., Schnabl P. \& Šlechta S., 2004 - Magnetostratigrafie sedimentů zachovaných $v$ jeskynich Nizkých Tater (Magnetostratigraphy of sediments preserved in caves located in the Nizke Tatry Mts.). In: Bella P. (Ed.) Research, Utilization and Protection of Caves 4. Slovak Caves Administration, Liptovský Mikuláš: 15-19. (In Czech with English abstract).

Kubiny D., 1961 - Krasové systémy v obalových sériách Západných a Nizkych Tatier. Slovenský Kras, 3 (19591960): 3-20. Martin. (In Slovak).

Lacelle D., 2007 - Environmental setting (micro) morphologies and stable C-O-isotope composition of cold climate carbonate precipitation. - A review and evaluation of their potential as paleoclimatic proxies. Quaternary Science Reviews, 26 (11-12): 1670-1689.

Lacelle D., Lauriol B. \& Clark I.D., 2006 - Effect of chemical composition of water on the oxygen-18 and carbon-13 signature preserved in cryogenic carbonates, Arctic Canada: Implications in paleoclimatic studies. Chemical Geology, 234 (1-2): 1-16.
Lacelle D., Lauriol B. \& Clark I.D., 2009 - Formation of seasonal ice bodies and associated cryogenic carbonates in Caverne de l'Ours, Québec, Canada. Kinetic isotope effects and pseudo-biogenic crystal structures. Journal of Cave and Karst Studies, 71: 48-62.

Lachniet M.S., 2009 - Climatic and environmental controls on speleothem oxygen-isotope values. Quaternary Science Reviews, 28: 412-432.

Lisiecki L.E. \& Raymo M.E., 2005 - A Pliocene-Pleistocene stack of 57 globally distributed benthic $\delta^{18} \mathrm{O}$ records. Paleooceanography, 20 (1): 1-17.

Louček D., 1956 - Ďumbirský velehorský kras. Rozpravy ČSAV, řada MPV, 66 (3): 1-44. Academia. Praha. (In Czech).

Louček D., Michovská J. \& Trefná E., 1960 - Glaciation of the Low Tatra Mountains. Sborník Československé společnosti zeměpisné, 65 (4): 326-352. (In Czech with English abstract).

Meyer M.C., Cliff R.A., Spötl C., Knipping M. \& Mangini A., 2009 - Speleothems from the earliest Quaternary: Snapshots of paleoclimate and landscape evolution at the northern rim of the Alps. Quaternary Science Reviews (2009), doi: 10.1016/j.quascirev.2009.01.010

Orvošová M., Uhlík P. \& Uher P., 2006 - Allochtónne sedimenty jaskýn̆ vysokohorského krasu Nizkych Tatier. In: Bella P. (Ed.) - Výskum, využivanie a ochrana jaskýn̆ 5. Slovak Caves Administration, Liptovský Mikuláš: 92-104. (In Slovak).

Orvošová M. \& Žák K., 2007 - Cryogenic carbonate precipitation in caves: Jaskyña Studeného Vetra Cave (Low Tatras, Slovakia) case study. In: Socha P., Stefaniak K., Tyc A. (Eds.) - Guidebook \& Abstracts, Karst and Cryokarst, 25th Speleological School and 8th GLACKIPR Symposium, Sosnowiec.Wrocław, Poland. Department of Geomorphology, University of Silesia, Sosnowiec: 104-105.

Richter D.K., Neuser R.D. \& Voigt S., 2008 - Kryogene Calciumpartikel aus der Heilenbecker Höhle in Ennepetal (NE Bergisches Land/Nordrhein-Westfalen) (Cryogenic calcite particle from the Heilenbecker Cave in Ennepetal, NE Bergisches Land/North-Rhine Westphalia). Die Höhle, 59 (1-4): 37-47.

Richter D.K. \& Niggemann S., 2005 - Kryogene Calcite in Höhlen des Rheinischen Schiefergebirges. Mitteilungen des Verbandes der deutschen Höhlenund Karstforscher e.V. München, 51 (4): 129-132.

Richter D.K. \& Riechelmann D.F.C., 2008 - Late Pleistocene cryogenic calcite spherolites from the Malachitdom Cave (NE Rhenish Slate Mountains, Germany): origin, unusual internal structure and stable $\mathrm{C}$-O isotope composition. International Journal of Speleology, 37 (2): 119-129.

Rossi G. \& Zorzin R., 1993 - Nuovi dati sui fenomeni paleocarsici dei Covoli di Velo (Monti Lessini - VR). Le Grotte d'Italia, XVI (Atti XVI Cong. Naz. Speleol., Udine 1990): 169-174.

Souchez R.A., Jouzel J., 1984 - On the isotopic composition in $\delta D$ and $\delta^{18} O$ of water and ice during freezing. Journal of Glaciology, 30 (106): 369-372.

Spötl C., 2008 - Kryogene Karbonate im Höhleneis der Eisriesenwelt. Die Höhle, 59 (1-4): 26-36. 
Štéc M., 1986 - Jaskyña Mŕtvych netopierov. Bulletin of the Slovak Speleological Society, 17 (1-2): 29-32. Martin. (In Slovak).

Štéc M., 1987 - Výsledky základného pozorovania niektorých mikroklimatických charakteristik $v$ jaskyni Mrtuych netopierov. Bulletin of the Slovak Speleological Society, 18 (1-2): 8-14. Liptovský Mikuláš. (In Slovak).

Štéc M., 1997 - Jaskyña Mŕtvych netopierov-vyhodnotenie skúšobného obdobia. Slovenský Kras, 35: 163-170. Liptovský Mikuláš. (In Slovak).

Štéc M., 1998 - Novoobjavená Jaskyña Studeného vetra $v$ Dumbierskom vysokohorskom krase. Bulletin of the Slovak Speleological Society, 29 (4): 7-9. Liptovský Mikuláš. (In Slovak).

Štéc M., 2000 - Sprievodca Ďumbierskym vysokohorským krasom, Jaskyña mŕtvych netopierov. Author-published booklet, without ISBN: 72 p. (In Slovak).

Štéc M., 2001 - Jaskyña studeného vetra - nová ladová jaskyña na Slovensku. Bulletin of the Slovak Speleological Society, 32 (1): 36-37. Prešov. (In Slovak).

Štéc M. \& Budaj M., 2005 - Významné objavy v Jaskyni mrtvych netopierov. Bulletin of the Slovak Speleological Society, 36 (1): 34-37. (In Slovak).

Tencer J., 2008a - Tabulka najdlhších jaskýn̆ na Slovensku. Bulletin of the Slovak Speleological Society, 39 (1): 40. (In Slovak).
Tencer J., 2008b - Tabulka najhlbšich jaskýn̆ na Slovensku. Bulletin of the Slovak Speleological Society, 39 (1): p. 41. (In Slovak).

Tulis J. \& Novotný L., 1989 - Jaskynný system Stratenskej jaskyne (System of Stratenská Cave). Osveta, Martin, 464 p. (In Slovak with Russian and English summary).

Tyc A., 2004 - Europe, Central. In: Gunn J. (Ed.) Encyclopedia of Caves and Karst Science. Fitzroy Dearborn, an imprint of the Taylor and Francis Group, New York, London: 331-333.

Uggeri S., 1992 - Analisi geologico ambientale di un massiccio carbonatico prealpino (M. Campo dei Fiori, Varese): geologia, geologia del Quaternario, idrogeologia. PhD Thesis, Univ. di Milano, 153 p.

Žák K., Onac B.P. \& Perşoiu A., 2008 - Cryogenic carbonates in cave environments. A review. Quaternary International, 187: 84-96.

Žák K., Urban J., Cílek V. \& Hercman H., 2004 Cryogenic cave calcite from several Central European caves: age, carbon and oxygen isotopes and a genetic model. Chemical Geology, 206: 119-136.

Zelinka J., 2003 - Dumbier Karst, Excursion Guide. In: Bella P. (Ed.) - Programme - Abstracts of Papers Excursion Guide, Research, Utilization and Protection of Caves 4, Tále, October 5-8, 2003. Slovak Caves Administration. Liptovský Mikuláš: pp. 15-19. 